\title{
The Biology and Ultrastructure of Phagotrophy in Ochromonas danica (Chrysophyceae: Chrysomonadida)
}

\author{
By S. AARONSON \\ Biology Department, Queens College, City University of New York, \\ Flushing, N.Y. I I 367 , U.S.A.
}

(Received 25 September 1973; revised 5 February 1974)

\begin{abstract}
S UM M A R Y
Ochromonas danica can obtain energy and required nutrients by eating several different bacteria or brewer's yeast. The phagocytic process includes aggregation of bacteria into clumps which contain and are surrounded by Ochromonas.

Bacteria were phagocytized too fast to be seen while yeast took at least $5 \mathrm{~min}$ to be engulfed. 2,4-Dinitrophenol or sodium azide, but not sodium fluoride or iodoacetic acid, inhibited the phagocytic process; aerobic energy metabolism was necessary for phagocytosis. Food organisms were engulfed and the food vacuole migrated to the posterior end of the organism behind the leucosin vacuole. The bacteria were digested mainly in the food vacuole although secondary lysosomes were formed. Digestion of bacteria resulted in the proliferation of vesicles and membranes from the food vacuole membrane and the proliferation of membrane from the bacteria being digested.
\end{abstract}

\section{IN TRODUCTION}

The biology and ultrastructure of the phagotrophic process (endocytosis) has been studied in relatively few protozoa (Pitelka, 1963; Müller, 1967; Aaronson, 1973a). Recently attention has been paid to phagotrophy in ciliates: Elliott \& Clemmons ( I 966) studied cytochemical ultrastructure in Tetrahymena pyriformis while the biology of Tetrahymena has been examined by many (Müller, 1967; Ricketts, 1970, 1971 $a, b$; Nilsson, 1972). The ultrastructure of phagocytosis in Colpoda was examined by Rudzinska, Jackson \& Tuffran (I966) and in Tokophrya by Rudzinska (1970). Amoebae have also received their share of attention (Chapman-Andresen, 1971), with ultrastructural studies of phagocytosis in Pelomyxa (Roth, 1960) and Entamoeba (Rosenbaum \& Wittner, 1970) and biological studies in Acanthamoeba (Weisman \& Moore, 1969; Rabinovitch \& DeStefano, 1971). To my knowledge there is little or no recent work on phagotrophy in flagellates particularly the phytoflagellates (Aaronson, I973a); hence Ochromonas danica was chosen for study.

Ochromonas danica is capable of phagotrophy, heterotrophy, photoheterotrophy and photoautotrophy (Pringsheim, 1955; Aaronson \& Baker, 1959). Earlier papers have presented information on the nutrition (Aaronson \& Baker, I959) and (briefly) the ultrastructure of phagotrophy (Schuster, Hershenov \& Aaronson, I968), while the chemical composition of photoheterotrophic and photophagotrophic $O$. danica were compared by Aaronson (1972). Further details of the biology and ultrastructure of phagotrophy in $O$. danica are presented in this paper. 
Table I. Phagotrophic mineral medium (PMM)

\begin{tabular}{|c|c|c|c|}
\hline Nitrilotriacetic acid & $0.2 \mathrm{~g}$ & $\mathrm{Mn}\left(\right.$ as $\mathrm{MnSO}_{4} \cdot \mathrm{H}_{2} \mathrm{O}$ ) & $5.0 \mathrm{mg}$ \\
\hline $\mathrm{KH}_{2} \mathrm{PO}_{4}$ & $0.3 \mathrm{~g}$ & $\mathrm{Cu}\left(\right.$ as $\left.\mathrm{CuSO}_{4} \cdot 5 \mathrm{H}_{2} \mathrm{O}\right)$ & $0.1 \mathrm{mg}$ \\
\hline $\mathrm{MgCO}_{3}$ (basic) & $0.4 \mathrm{~g}$ & $\mathrm{Co}\left(\right.$ as $\left.\mathrm{CoSO}_{4} \cdot 7 \mathrm{H}_{2} \mathrm{O}\right)$ & $0.1 \mathrm{mg}$ \\
\hline $\mathrm{CaCO}_{3}$ & $0.05 \mathrm{~g}$ & $\mathrm{~B}\left(\right.$ as $\mathrm{H}_{3} \mathrm{BO}_{3}$ ) & $0.1 \mathrm{mg}$ \\
\hline $\mathrm{NH}_{4} \mathrm{Cl}$ & $0.5 \mathrm{~g}$ & Mo [as $\left.\left(\mathrm{NH}_{4}\right)_{6} \mathrm{Mo}_{7} \mathrm{O}_{24} \cdot 4 \mathrm{H}_{2} \mathrm{O}\right]$ & $0.05 \mathrm{mg}$ \\
\hline $\mathrm{MgSO}_{4} \cdot 7 \mathrm{H}_{2} \mathrm{O}$ & $\mathrm{I} .0 \mathrm{~g}$ & $\mathrm{~V}$ [as $\left.\mathrm{Na}_{3} \mathrm{VO}_{4} . \mathrm{I} 6 \mathrm{H}_{2} \mathrm{O}\right]$ & $0.05 \mathrm{mg}$ \\
\hline $\mathrm{Fe}\left[\right.$ as $\left.\mathrm{Fe}\left(\mathrm{NH}_{4}\right)_{2}\left(\mathrm{SO}_{4}\right)_{2} \cdot 6 \mathrm{H}_{2} \mathrm{O}\right]$ & $13.0 \mathrm{mg}$ & Distilled water & I 1 \\
\hline $\mathrm{Zn}\left(\right.$ as $\left.\mathrm{ZnSO}_{4} \cdot 7 \mathrm{H}_{2} \mathrm{O}\right)$ & $8.0 \mathrm{mg}$ & $\mathrm{pH} 5 \cdot 0$ & \\
\hline
\end{tabular}

\section{METHODS}

Cultures of $O$. danica Pringsheim (strain 933/2; Culture Centre of Algae and Protozoa, Cambridge) for inoculation were maintained axenically in a chemically defined medium (Aaronson \& Baker, I959) in white fluorescent light at $25^{\circ} \mathrm{C}$ in a refrigerated incubator. For phagotrophic experiments cultures were grown axenically in phagotrophic medium (PMM) (Table I) for periods of up to two weeks with 125 to I $50 \mathrm{ft}$-candle of white fluorescent light as above. As PMM contained no carbon source for energy and no required vitamin, photoautotrophy or heterotrophy was impossible. Bacteria were grown in $500 \mathrm{ml} \mathrm{BBL}$ nutrient broth for 3 to 4 days at $37^{\circ} \mathrm{C}$, harvested at $4300 \mathrm{~g}$ in a Sorval RC-2B refrigerated centrifuge at $4{ }^{\circ} \mathrm{C}$ and washed twice with 30 to $40 \mathrm{ml}$ distilled water before being suspended in distilled water or PMM for use as a bacterial suspension. Brewer's yeast was suspended in distilled water for $\mathrm{I} h$ in the refrigerator; only the smaller yeast cells which remained suspended were used. Carbon particle phagotrophy was studied by suspending $O$. danica in indian ink (Higgins) diluted with distilled water to yield an absorbance of about 0.6 to 0.8 at $4 \mathrm{IO} \mathrm{nm}$ in a Beckman DB spectrophotometer.

Cell multiplication was determined by taking a culture sample, killing the cells with a drop of $0.125 \% \mathrm{HgCl}_{2}$, and counting them with a haemocytometer. For determining the kinetics and energy metabolism of phagotrophy, a yeast suspension was inoculated with $O$. danica, incubated, and samples taken out at appropriate time intervals; the samples were killed with $\mathrm{HgCl}_{2}$ and the numbers of $O$. danica containing yeast in samples of 100 were counted with a light microscope and recorded as the percentage of organisms eating.

Organisms for ultrastructural studies were centrifuged at $860 \mathrm{~g}$ in a Sorval angle centrifuge for $5 \mathrm{~min}$; pellets were fixed for $\mathrm{I} h$ in $2.5 \%(\mathrm{w} / \mathrm{v})$ glutaraldehyde containing a trace of $\mathrm{CaCl}_{2}$ and buffered with sodium cacodylate $(0 \cdot \mathrm{I} \mathrm{M})$ at $\mathrm{pH} 7 \cdot 4$. After two rinses in cacodylate buffer the organisms were postfixed for $\mathrm{I} h$ in $\mathrm{I} \%(\mathrm{w} / \mathrm{v})$ osmic acid buffered with sodium cacodylate $(\mathrm{O} \cdot \mathrm{I} \mathrm{M})$ at $\mathrm{pH} 7 \cdot 4$. During fixation pellets were placed on crushed ice. After the osmic acid was removed, the pellets were stained in $\mathrm{I} \%(\mathrm{w} / \mathrm{v})$ aqueous uranyl acetate for $20 \mathrm{~min}$ at room temperature and then dehydrated in a graded alcohol series. After clearing in propylene oxide, the organisms were embedded in Epon 8I 2 which was polymerized at $60{ }^{\circ} \mathrm{C}$ for $48 \mathrm{~h}$. Sections, cut with a diamond knife on an MT-2 Porter-Blum ultramicrotome, were stained with uranyl acetate and lead citrate. Micrographs were taken with a Philips 300 or Jeolco T7 electron microscope.

All chemicals were reagent grade obtained commercially and used without further purification.

\section{RESULTS}

\section{Biology and gross morphology of phagotrophy}

Earlier results (Aaronson, 1972) indicated that $O$. danica was able to grow and multiply on Aerobacter aerogenes, the classic organism for phagotrophic studies. Several other 
Table 2. Ability of micro-organisms to support $O$. danica multiplication

$\begin{array}{lc}\text { Organism (10 mg/ } 100 \mathrm{ml}) & \begin{array}{c}\mathrm{IO}^{-6} \times \text { No. of cells/ml } \\ \text { after I week* }\end{array} \\ \text { Escherichia coli } & 20.9 \\ \text { Proteus mirabilis } & 13.8 \\ \text { Aerobacter acrogenes } & 11.7 \\ \text { Bacillus megaterium } & 6.0 \\ \text { Sarcina lutea } & 10 \cdot 8 \\ \text { Serratia marcescens } & 6.4 \\ \text { Brewer's yeast } & 4.9 \\ \quad \text { * Inoculum }=20000 \text { cells } / \mathrm{ml} & \end{array}$

Table 3. Clearance of particles in aqueous suspension by $O$. danica in $48 h^{\text {* }}$

\begin{tabular}{lcc} 
& \multicolumn{2}{c}{ Absorbance at $410 \mathrm{~nm}$} \\
\cline { 2 - 3 }$\quad$ Without $O$. danica & With $O$. danica \\
Indian ink & 0.87 & 0.46 \\
Aerobacter aerogenes & 0.35 & 0.15 \\
Pseudomonas aeruginosa & 0.22 & 0.11
\end{tabular}

* Each tube contained $5 \mathrm{ml}$ of particle suspension inoculated with approx. $3.6 \times 10^{6}$ light-grown, 6-dayold cells.

bacteria and a yeast were found to support $O$. danica multiplication in PMM (Table 2). All micro-organisms tested were able to support the multiplication of $O$. danica, though some were more effective than others.

When $A$. aerogenes $(2 \cdot 0 \mathrm{mg} / \mathrm{ml})$ was suspended in $500 \mathrm{ml} \mathrm{PMM}$ in a I 1 Erlenmeyer flask with or without a small inoculum $(20000$ cells $/ \mathrm{ml})$ of light-grown $O$. danica, the cell suspension appeared white. After 3 to 4 days of incubation in the light at $25^{\circ} \mathrm{C}$ the bacterial cell suspension containing Ochromonas began to aggregate into tiny clumps. By the 7 th day, the suspension was much clearer with a light greenish-yellow colour and larger clumps or aggregates suspended throughout the medium; the number of $O$. danica had increased about 17 -fold $(20000$ to 336000 cells $/ \mathrm{ml}$ ). The control flask without added Ochromonas remained as a white bacterial suspension for 2 weeks of incubation. Microscopic examination of the clumps revealed aggregations of bacteria surrounded and occasionally invaded by Ochromonas. The Ochromonas were immobile in the clump but swam about actively when the clump was broken or disturbed.

The capture of food, one of the first steps in phagocytosis, in $O$. danica involved the flow of the liquid medium toward and over the surface of the organism, induced by flagellar action (Aaronson, 1973 $h$ ). This flow led to the trapping of suspended particles on or near the cell surface followed by particle engulfment (Table 3). Small particles (carbon or bacteria) were engulfed more rapidly than the eye could follow in the light microscope (Pringsheim, 1955). Yeast were engulfed more slowly; almost five min were required before they were inside Ochromonas. Mixing Ochromonas with a suspension of carbon or bacteria led to aggregation of the particles. This was attributed to the membranous vesicles and other substances secreted by Ochromonas into its environment (Aaronson, 1971; Aaronson, Behrens, Orner \& Haines, 1971; Aaronson, 1973 b). These vesicles and associated substances were believed to act like 'flypaper', causing particles to stick to the Ochromonas surface or to each other until groups of aggregated particles became large enough to be seen with the 
Table 4. Kinetics of phagocytosis of yeast cells by $O$. danica

\begin{tabular}{|c|c|c|c|c|c|}
\hline \multicolumn{3}{|c|}{$\begin{array}{c}O . \text { danica containing } \\
\text { one or more yeast cells } \\
(\%)\end{array}$} & \multicolumn{3}{|c|}{$\begin{array}{l}\text { O. danica } \\
\text { one or more }\end{array}$} \\
\hline Time (min) & \multicolumn{2}{|c|}{ Mean \pm s.D. } & & Time (min) & Mean \\
\hline 5 & \multicolumn{2}{|c|}{$8 \pm 6$} & & 35 & \\
\hline 10 & \multicolumn{2}{|c|}{$17 \pm 5$} & & 40 & \\
\hline 15 & \multicolumn{2}{|c|}{$23 \pm I$} & & 45 & \\
\hline 20 & \multicolumn{2}{|c|}{$32 \pm 3$} & & 50 & \\
\hline 25 & \multirow{2}{*}{\multicolumn{2}{|c|}{$\begin{array}{l}47 \pm 8 \\
5 I+8\end{array}$}} & & 55 & \\
\hline 30 & & & & 60 & \\
\hline \multicolumn{6}{|c|}{ Effect of metabolic poisons on the phagotrophy of yeast cel } \\
\hline & & \multicolumn{4}{|c|}{ Phagotrophy (as $\%$ of control)* } \\
\hline & & \multicolumn{4}{|c|}{ Metabolic poisons } \\
\hline \multicolumn{2}{|c|}{ Conen (M) } & $\begin{array}{c}\text { Sodium } \\
\text { azide }\end{array}$ & Dnp & $\begin{array}{l}\text { Iodoacetic } \\
\text { acid }\end{array}$ & $\mathrm{NaF}$ \\
\hline \multicolumn{2}{|c|}{0} & 100 & 100 & 100 & 100 \\
\hline \multicolumn{2}{|c|}{$1 \times 10^{-6}$} & 94 & 84 & $8 \mathrm{I}$ & 78 \\
\hline \multicolumn{2}{|c|}{$5 \times 10^{-6}$} & 85 & 40 & 80 & 74 \\
\hline \multicolumn{2}{|c|}{$1 \times 10^{-5}$} & 24 & 8 & 88 & 98 \\
\hline \multicolumn{2}{|c|}{$5 \times 10^{-5}$} & 4 & 0 & 66 & 98 \\
\hline \multicolumn{2}{|c|}{$1 \times 10^{-4}$} & 0 & 0 & 42 & 83 \\
\hline \multicolumn{2}{|c|}{$5 \times 10^{-4}$} & 0 & o & $\begin{array}{r}4-2 \\
9\end{array}$ & 84 \\
\hline \multicolumn{2}{|c|}{$1 \times 10^{-3}$} & 0 & 0 & 0 & 89 \\
\hline
\end{tabular}

* Average of three trials. Similar results were obtained by several people in many trials.

unaided eye or to precipitate (Aaronson, $1973 \mathrm{~b}$ ). Clumping of bacteria by protozoan predators was also seen by Hardin (I943) to occur with the flagellate Oikomonas, and by H. M. Tsuchiya (personal communication) with the ciliates Tetrahymena, Dictyostelium and Colpoda.

\section{Kinetics and energy metabolism of phagotrophy}

A suspension of brewer's yeast cells was made in PMM or distilled water and inoculated with $O$. danica; portions were successively removed and examined for phagotrophy. Ochromonas danica ate yeast within $5 \mathrm{~min}$, and more than $50 \%$ of the Ochromonas were eating within $30 \mathrm{~min}$ (Table 4 ). At no time were $100 \%$ of the organisms eating, although sometimes as many as $75 \%$ were doing so.

Attempts were made to determine if phagotrophy required aerobic, anaerobic or both forms of energy metabolism. Ten million yeast cells and an equal number of $O$. danica cells were incubated in $5 \mathrm{ml} \mathrm{PMM}$ in a tube for $1 \mathrm{~h}$ in $170 \mathrm{ft}$-candle of white light at $25^{\circ} \mathrm{C}$ in the presence of appropriate concentrations of metabolic poisons. Samples were removed and the cells killed and counted (Table 5). It is clear that $O$. danica phagotrophy was more dependent on aerobic than anaerobic energy metabolism, as the uncoupler of aerobic oxidative phosphorylation (2,4-Dnp) and the inhibitor of electron transport (sodium azide) were more effective inhibitors of phagotrophy than inhibitors of glycolysis ( $\mathrm{NaF}$ and iodoacetic acid). That phagotrophy was dependent on metabolic activity may also be seen from Table 6, which shows that eating increased with increasing temperature. Short term ( $\mathrm{I} \mathrm{h}$ ) incubation at $25{ }^{\circ} \mathrm{C}$ in the light ( $18 \%$ eating) was not much different from dark incubation ( $20 \%$ eating). 


\section{Table 6. Effect of temperature on $O$. danica phagotrophy}

$\begin{array}{cc}\text { Temperature }(\mathrm{C})^{*} & \begin{array}{c}\text { Cells showing phagotrophy } \\ \text { in } \mathrm{I} h(\%) \dagger\end{array} \\ \text { IO (15) } & 6 \pm 2 \\ 15(25) & 8 \pm 3 \\ 20(25) & 14 \pm 3 \\ 25(25) & 19 \pm 3 \\ 30(28) & 2 \mathrm{I} \pm 4 \\ * \text { No. of trials given in parentheses. } \\ \dagger \pm \text { s.D. }\end{array}$

\section{Ultrastructure of phagotrophy and digestion}

The appearance of phagotrophic organisms during eating and digestion was studied by examining $O$. danica periodically in an autoclaved bacterial or yeast suspension over a period of $90 \mathrm{~min}$ and then (with bacteria) for up to 9 days. Attempts to examine the fine structure of the phagocytosis of yeast were not successful because the yeast tended to break out of thin sections. The few intact sections examined indicated that the yeast were taken into large food vacuoles at the sides of the organism; these food vacuoles then seemed to migrate to the posterior part of the Ochromonas behind the leucosin vacuole. Food vacuoles containing bacteria seemed to form within what appeared to be seconds of contact at the sides and front of Ochromonas; they were then seen by light microscopy to migrate toward the rear of the organism. Similar observations were made by Pringsheim (1952, 1955). The appearance of the bacteria after incubation in PMM without $O$. danica for 2 days (Fig. 1) showed relatively little physical change; the bacterial cell envelope lifted off the cell mass and there was some decrease in density of the bacterial cytoplasm, but no membranous vesicle was seen in the medium or attached to the bacterial cells. The appearance after 9 days was almost identical. Membranous vesicles were found only at the surface of or associated with the presence of $O$. danica (Fig. 3). Short term (minute or hour) incubation of bacteria and Ochromonas did not seem to clarify further the phagotrophic or digestive process; longer incubations were therefore undertaken. After two days of incubation in PMM containing $O$. danica, bacteria were found throughout the Ochromonas cytoplasm in food vacuoles (Fig. 2), which tended to coalesce at the posterior part of the organism to form larger vacuoles containing bacteria in various stages of digestion (Fig. 3). The surface membranes of the large food vacuoles produced small vesicles (Figs. 3,6) which presumably contained digestive enzymes, although there was no direct evidence for this. After four days of incubation the food vacuoles appeared enormous, occupying a great part of the cell volume and compressing the large leucosin vacuole; bacteria in various stages of digestion were also to be seen (Fig. 3). The smaller migrating food vacuoles seemed to empty into the enlarged posterior food vacuole (Fig. 3). After six days the food vacuoles contained many small vesicles, which were seen at all times but not in such large numbers. The small vesicles reported elsewhere (Aaronson et al. 1971) were also seen in the extracellular environment attached to or near bacteria. After nine days, relatively few Ochromonas contained bacteria, although bacteria were still present in the medium. This may be due to an inhibition of phagotrophy by the accumulation of extracellular nutrients resulting from the phagotrophic and digestive processes or extracellular digestion (Aaronson, 1973a), although there is no specific evidence for a mechanism.

Details of the digestion of bacteria in the food vacuole may be seen in Figs. 4 and 6. 

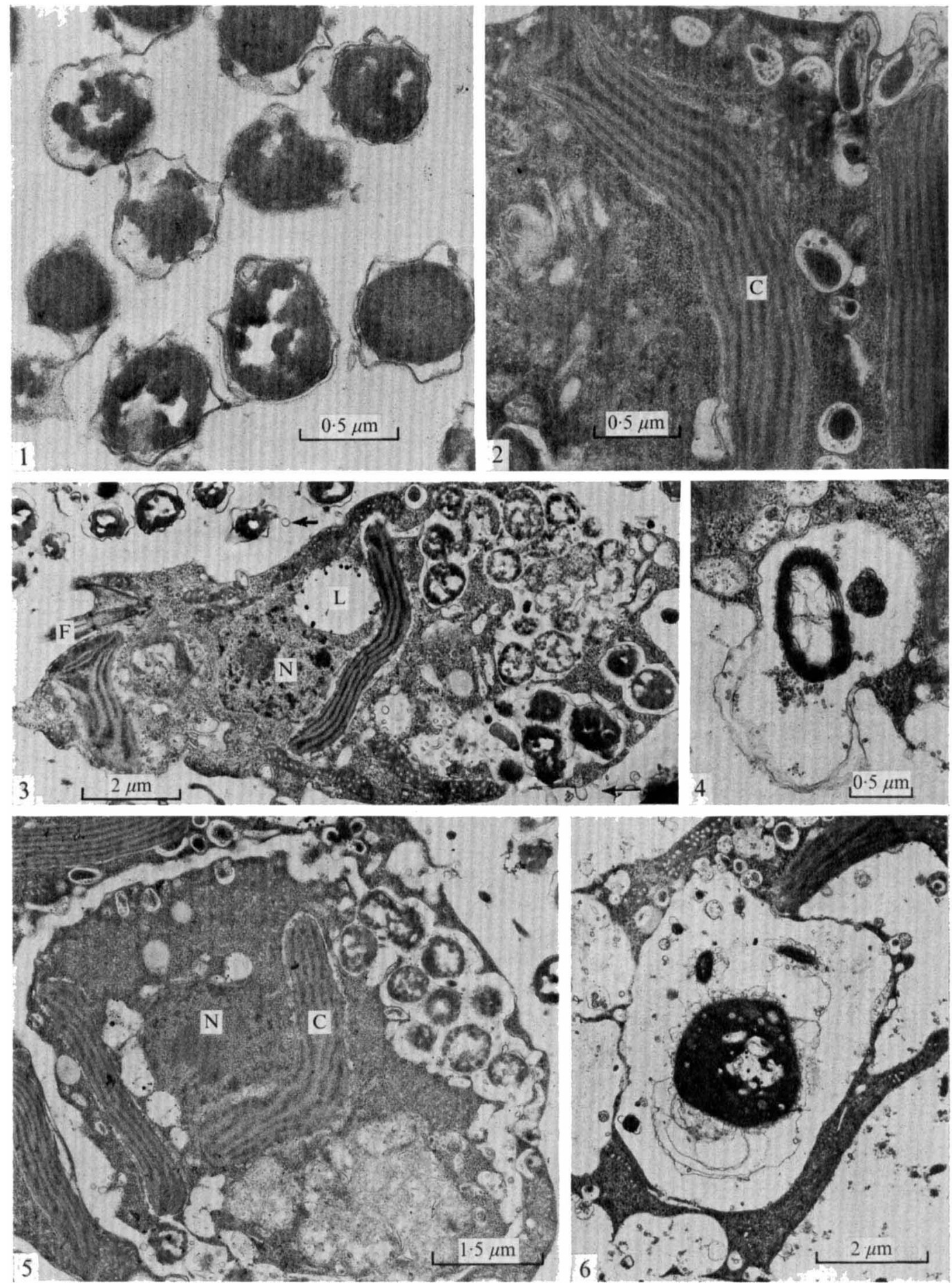
The bacterial surface seemed to ripple and form membrane (Fig. 6) which was joined by a proliferation of membranes and vesicles from the food vacuole membrane (Fig. 6). Smaller vacuoles containing electron-dense material which may be secondary lysosomes are shown in Figs. 5 and 6. Ochromonas as well as bacteria were sometimes found in the same food vacuole (Fig. 5).

\section{DISCUSSION}

Ochromonas danica is capable of surviving and multiplying by phagocytizing one or several bacterial species, a yeast and as reported by Daley, Morris \& Brown (1973), a bluegreen alga. Ochromonas resembles some other protozoa which are quite unselective in their ability to use a variety of food organisms; other protozoa are more selective, able to grow and multiply on only a limited number of food organisms (Hall, I965); some protozoa eat a variety of organisms but will select specific species if given a choice (Rapport, Berger \& Reid, 1972).

The chemical composition of other protozoa grown on soluble nutrients and on bacteria has not to my knowledge been reported. Ochromonas danica grown photophagotrophically on $A$. aerogenes produced fewer cells because there was less energy and organic material available in the bacteria; they contained less protein and carbohydrate and more total lipids than cells grown under the same physical conditions photoheterotrophically on a chemically defined medium (Aaronson, I 972).

Few attempts have been made to study the energy metabolism of the phagotrophic process in protozoa; some have used metabolic poisons such as inhibitors of glycolysis (fluoride and iodoacetate), of aerobic respiration (cyanide and azide) and an uncoupler of oxidative phosphorylation (2,4-dinitrophenol). Cyanide, azide and Dnp, but not fluoride or iodoacetate, inhibited phagocytosis in Acanthamoeba sp. (Weisman \& Korn, 1967). Ochromonas danica were more sensitive to some of these inhibitors than were the amoebae; azide and Dnp at about $10^{-5} \mathrm{M}$ were very inhibitory. Iodoacetate was appreciably less inhibitory, and fluoride was not inhibitory at the tested concentrations. Hill (1972) noted that food vacuole formation in Tetrahymena was stopped by Dnp, but offered no data. It is apparent that the three aerobic protozoa described above depend on aerobic oxidative metabolism for energy for phagocytosis. Mammalian macrophages seem to be more variable; peritoneal macrophages tend to be faculative anaerobes while alveolar macrophages seem to be facultative aerobes (Pearsall \& Weiser, 1970).

Fig. I. Appearance of Aerobacter aerogenes in suspension in PMM for 2 days with no Ochromonas present. Note absence of membranous vesicles in medium around bacteria.

Fig. 2. Ochromonas danica after 2 days of incubation in a bacterial suspension. Food vacuoles at cell surface (upper right) and in cytoplasm at anterior end of organism.

Fig. 3. Ochromonas danica after 2 days of incubation with bacteria. Note membranous vesicles outside the Ochromonas or at its surface (arrows) and compressed leucosin vacuole. Large food vacuoles with many bacteria in various stages of digestion at the posterior end (right).

Fig. 4. Food vacuole with a bacterium almost completely digested; only membrane and bacterial perimeter remain.

Fig. 5. Food vacuole containing an Ochromonas and bacteria. Secondary lysosomes appear at top of figure.

Fig. 6. Food vacuole with a partially digested bacterium from which membranes seem to be proliferating. Secondary lysosomes are seen near the surface of the food vacuole at the top of the figure.

Symbols: $\mathrm{C}$, chloroplast; $\mathrm{F}$, flagellum; $\mathrm{L}$, leucosin vacuole; $\mathrm{N}$, nucleus. 
The microscopic and ultrastructural details of bacterial phagocytosis and digestion indicate that bacteria were engulfed and food vacuoles formed in the anterior end or at the sides of the organism, and the food vacuoles migrated posteriorly behind rather than into the leucosin vacuole as claimed by Daley et al. (1973). Here the food vacuoles fused to form a large food vacuole at the expense of the leucosin vacuole which was compressed. The food vacuole membrane produced small vesicles and membrane, which presumably were associated with the secretion of hydrolases into the food vacuole and formed secondary lysosomes for the further cytoplasmic digestion of the material from the food vacuole. The ultrastructure of digestion showed features similar to those described in other phagocytic protozoa, including accumulation of vesicles (presumably containing hydrolytic enzymes) at the inner surface of the food vacuole, as seen in the amoeba Pelomyxa (Roth, 1960) and in the ciliates Tokophrya (Rudzinska, I970) and Colpoda (Rudzinska et al. 1966). The digested bacteria seemed to produce large quantities of membrane which accumulated in the food vacuole, as in amoebae (Gezelius, I959, I96I; Mercer \& Shaffer, I960; Vickerman, I960; Schuster, 1964; Spies \& Elbers, 1972), the amoebo-flagellate Naegleria (Schuster, 1963) and the ciliate Colpoda (Rudzinska et al. 1966).

The phagotrophic process of $O$. danica offers several features not previously described in protozoa; these include particle aggregation, fluid flow induced by the flagella carrying food organisms to the anterior end, the 'flypaper' effect of the Ochromonas surface, and the flow of food vacuoles to the posterior end and their fusion there into a large food vacuole independent of the leucosin vacuole.

The author is indebted to Ms U. Behrens for the electron micrographs, to L. Ardois and S. Friedman for some of the phagotrophic metabolism experiments, and to J. Bodnaruk of the Department of Chemical Engineering, City College, City University of New York, for the use of the electron microscope. This work was done with the support of grants GB7833 and GB20825 from the National Science Foundation.

\section{REFERENCES}

Aaronson, A. (1971). The synthesis of extracellular molecules and membranes by a population of the phytoflagellate Ochromonas danica. Limnology and Oceanography 16, I-9.

AARONSON, S. (1972). A new source of single-cell protein and other nutrients. Archiv fiur Hydrobiologie 4r, IO8-II5.

Aaronson, S. (1973a). Digestion in flagellates. In Lysosomes in Biology and Medicine, vol. 3, pp. I8-27. Edited by J. T. Dingle. Amsterdam: North-Holland Publishing.

AARONSON, S. (1973b). Particle aggregation and phagotrophy by Ochromonas. Archiv fiir Mikrobiologic 92, 39-44.

AARONSON, S. \& BAKER, H. (1959). A comparative biochemical study of two species of Ochromonas. Journal of Protozoology 6, 282-284.

atronson, S., Behrens, U., Orner, R. \& Haines, T. H. (1971). Ultrastructure of intracellular and extracellular vesicles, membranes, and myelin figures produced by Ochromonas danica. Journal of Ultrastructure Research 35, 4I8-430.

Chapman-Andresen, C. (1971). Biology of the large amoebae. Annual Review of Microbiology 25, $27-48$.

Daley, R. J., Morris, G. P. \& Brown, S. R. (1973). Phagotrophic ingestion of a blue-green alga by Ochromonas. Journal of Protozoology 20, 58-6r.

Elliotr, A. M. \& Clemmons, G. L. (I966). An ultrastructural study of ingestion and digestion in Tetrahymena pyriformis. Journal of Protozoology 13, 31 I-323.

Gezelius, K. (1959). The ultrastructure of cells and cellulose membranes in acrasiae. Experimental Cell Research 18, 425-453.

Gezelius, K. (1961). Further studies in the ultrastructure of acrasiae. Experimental Cell Research 23, 300-310. 
Hall, R. P. (1965). Protozoan Nutrition, pp. 31-32. New York: Blaisdell Publishing Co.

Hardin, G. (I943). Flocculation of bacteria by protozoa. Nature, London $\mathbf{1 5} \mathbf{1}, 642$.

HrL., D. L. (1972). The Biochemistry and Physiology of Tetrahymena, p. I4. New York: Academic Press.

Mercer, E. H. \& Shaffer, B. M. (I960). Electron microscopy of solitary and aggregated slime mold cells. Journal of Biophysical and Biochemical Cytology 7, 353-356.

Müller, M. (1967). Digestion. In Chemical Zoology, vol. I, The Protozoa, pp. 35I-380. Edited by M. Florkin and B. T. Scheer. New York: Academic Press.

Nilsson, J. R. ( I 972). Further studies on vacuole formation in Tetrahymena pyriformis GL. Compte rendu des travaux du Laboratoire Carlsberg 39, 83-110.

Pearsall, N. N. \& Weiser, R. S. (1970). The Macrophage, pp. 42-43. Philadelphia: Lea \& Febiger.

PitelkA, D. R. (1963). Electron-microscopic Structure of Protozoa. Oxford: Pergamon Press.

Pringsheim, E. G. (1952). On the nutrition of Ochromonas. Quarterly Journal of Microscopical Science $\mathbf{9 3}$, $71-96$.

Pringsheim, E. G. (I955). Über Ochromonas danica n. sp. und andere Arten der Gattung. Archiv fïr Mikrobiologie 23, I8 I-I92.

Rabinovitch, M. \& DeStefano, M. J. (197I). Phagocytosis of erythrocytes by Acanthamoeba sp. Experimental Cell Research 64, 275-284.

RApport, D. J., Berger, J. \& ReID, D. B. W. (1972). Determination of food preference of Stentor coeruleus. Biological Bulletin 142, $103-109$.

RICKETTS, T. R. ( 1970 ). Effect of endocytosis upon acid phosphatase activity of Tetrahymena pyriformis. Protoplasma 7r, I 27-I 37.

Ricketts, T. R. (1971 a). Periodicity of endocytosis in Tetrahymena pyriformis. Protoplasma 73, 387-396.

RICKETTS, T. R. (I97I b). Endocytosis in Tetrahymena pyriformis. Experimental Cell Research 66, 49-58.

Rosenbaum, R. M. \& WitTNER, M. (1970). Ultrastructure of bacterized and axenic trophozoites of Entamoeba histolytica with particular reference to helical bodies. Journal of Cell Biology 45, 367-382.

Roth, L. E. (1960). Electron microscopy of pinocytosis and food vacuoles in Pelomyxa. Journal of Protozoology $7,176-185$.

RudzinsKa, M. A. (1970). The mechanism of food intake in Tokophrya infusionum and ultrastructural changes in food vacuoles during digestion. Journal of Protozoology 17, 626-64I.

Rudzinska, M. A., Jackson, G. J. \& Tuffran, M. (1966). The fine structure of Colpoda maupasi with special emphasis on food vacuoles. Journal of Protozoology 13, 440-459.

SChuster, F. (1963). An electron microscope study of the amoeboflagellate, Naegleria grïberi (Schardinger). I. The amoeboid and flagellate stages. Journal of Protozoology ro, 297-3 13.

Schuster, F. (1964). Electron microscope observations on spore formation in the true slime mold Didymium nigripes. Journal of Protozoology Ir, 207-2 I6.

Schuster, F. L., Hershenov, B. \& Aaronson, S. (1968). Ultrastructural observations on aging of stationary cultures and feeding in Ochromonas. Journal of Protozoology 15, 335-346.

Spies, F. \& Elbers, P. F. (1972). Axenic mass cultivation of Entamoeba invadens and cell membrane isolation. Journal of Protozoology 19, 102-107.

Vickerman, K. ( 1960 ). Patterns of cellular organization in limax amoebae. Experimental Cell Research 26 , 497-519.

Weisman, R. A. \& Korn, E. D. (1967). Phagocytosis of latex beads by Acanthamoeba. I. Biochemical properties. Biochemistry 6, 485-497.

Weisman, R. A. \& Moore, M. O. (1969). Bead uptake as a tool for studying differentiation in Acanthamoeba. Experimental Cell Research 54, 17-22. 